\title{
Desregulação na expressão de genes de células progenitoras em infecção por Zika vírus
}

\author{
Deregulation in gene expression of progenitor cells in Zika virus infection
}
Desregulación de la expresión génica de las células progenitoras en la infección por el virus del Zika

Murilo Tavares Amorim ${ }^{1 *}$, Gustavo Moraes Holanda², Karla Fabiane Lopes de Melo ${ }^{3}$, Francisco Canindé Ferreira de Luna ${ }^{3}$, Walter Felix Franco Neto $^{4}$, Ana Paula Sousa Araújo ${ }^{4}$, Samir Mansour Moraes Casseb ${ }^{4}$, Jardel Fábio Lopes Ferreira ${ }^{3}$.

\section{RESUMO}

Objetivo: Descrever a infecção pelo Vírus Zika (VZIK) em células progenitoras e desordem em expressão gênica a partir de seus mediadores, os RNAs não-codificantes (ncRNAs). Métodos: Estudo observacional, de base transversal do tipo revisão integrativa. Foram selecionados artigos disponibilizados pelas plataformas: Nature, Medical Literature Analysis and Retrieval System Online (Medline), Science Direct e Repositório Digital do Instituto Evandro Chagas (Patuá), fundamentados pela busca de hipóteses relacionadas às alterações na expressão de ncRNAs, resultando em alterações fisiológicas em células progenitoras a partir da infecção por VZIK. Resultados: Foram obtidos 72 estudos relacionados a expressão de ncRNAs em infecções por vírus Zika, sendo definidos 8, que retratavam a proposta do tema. Estes, estabeleciam uma verossimilhança na abordagem do objeto de pesquisa, baseada na função dos ncRNAs, relação epigenética em infecção por VZIK e ativação de mediadores imunológicos, descrevendo a expressão de produtos gênicos associados a processos celulares correspondentes aos recursos de defesa do hospedeiro e aos mecanismos de replicação viral. Considerações Finais: Assim, observou-se a importância de estudos que proporcionem a contribuição técnica experimental, sobre os mecanismos de replicação viral, tropismo celular, atividade imunogenética, de modo a fomentar a contribuição científica para o controle do VZIK.

Palavras-chave: Zika vírus, Crna, IncRNA, miRNA, Células progenitoras.

\begin{abstract}
Objective: To describe the infection by the Zika Virus (VZIK) in progenitor cells and disorder in gene expression from its mediators, non-coding RNAs (ncRNAs). Methods: Observational, cross-sectional of the integrative review type. Articles made available by the platforms: Nature, Medical Literature Analysis and Retrieval System Online (Medline), Science Direct and Digital Repository of the Evandro Chagas Institute (Patuá) were selected, based on the search for hypotheses related to changes in the expression of ncRNAs, resulting in physiological changes in progenitor cells from VZIK infection. Results: 72 studies related to the expression of ncRNAs in Zika virus infections were obtained, of which 8 were defined, which portrayed the theme proposal. These established a verisimilitude in the approach of the research object, based on the function of ncRNAs, epigenetic relationship in VZIK infection and activation of immunological mediators, describing the expression of gene products associated with cellular processes corresponding to the host's defense resources and mechanisms viral replication. Final Considerations: Thus, it was observed the importance of studies that provide the experimental technical contribution, on the mechanisms of viral replication, cell tropism, immunogenetic activity, in order to foster the scientific contribution to the control of VZIK.
\end{abstract}

Keywords: Zika virus, ncRNA, IncRNA, miRNA, Progenitor cells.

${ }^{1}$ Centro Universitário Fibra, Belém - PA. * E-mail: murilotavares35@gmail.com

2 Universidade da Amazônia (UNAMA), Belém - PA.

${ }^{3}$ Universidade Federal do Pará (UFPA), Belém - PA.

${ }^{4}$ Instituto Evandro Chagas (IEC), Belém - PA. 


\section{RESUMEN}

Objetivo: Describir la infección por el virus del Zika (VZIK) en células progenitoras y el trastorno en la expresión génica de sus mediadores, los ARN no codificantes (ncRNA). Métodos: Estudio observacional, transversal del tipo revisión integradora. Se seleccionaron los artículos puestos a disposición por las plataformas: Nature, Medical Literature Analysis and Retrieval System Online (Medline), Science Direct y Repositorio Digital del Instituto Evandro Chagas (Patuá), a partir de la búsqueda de hipótesis relacionadas con cambios en la expresión de ncRNAs, resultando en cambios fisiológicos. en células progenitoras de la infección por VZIK. Resultados: Se obtuvieron 72 estudios relacionados con la expresión de ncRNAs en infecciones por virus Zika, de los cuales se definieron 8, que retrataron la propuesta temática. Estos establecieron una verosimilitud en el abordaje del objeto de investigación, basado en la función de ncRNAs, relación epigenética en la infección por VZIK y activación de mediadores inmunológicos, describiendo la expresión de productos génicos asociados a procesos celulares correspondientes a los recursos y mecanismos de defensa del huésped replica viral. Consideraciones Finales: Así, se observó la importancia de estudios que brinden el aporte técnico experimental, sobre los mecanismos de replicación viral, tropismo celular, actividad inmunogenética, con el fin de fomentar el aporte científico al control de VZIK.

Palabras clave: Zika Vírus, ncRNA, IncRNA, miRNA, Células progenitoras.

\section{INTRODUÇÃO}

O vírus Zika (VZIK) teve sua descoberta há cerca de 70 anos a partir do macaco do gênero rhesus (macaca mulata) que servia de sentinela para estudos com Vírus da Febre Amarela, em Uganda na África. No entanto,o o primeiro relato de infeção em humanos ocorreu somente na década de 50, na Nigéria, despertando atenção pela comunidade científica.

Em uma nova tentativa de realização do isolamento do vírus da febre amarela, obteve-se em uma mesma região, uma estirpe de VZIK, a partir de mosquitos Aedes africanus (estirpe E/1), posteriormente inoculada via subcutânea em macacos rhesus, cujo soro preponderou a capacidade de neutralizar tanto a estirpe E/1, quanto outra estirpe denominada 766, corroborando assim, à hipótese de que o VZIK permanecia naquela região, a partir de uma natureza endêmica, por meio do ciclo silvestre, circulando entre os mosquitos e os macacos africanos locais (BROGUEIRA P e MIRANDA AC, 2017).

Considerada como uma infecção benigna, a arbovirose ocasionada pelo VZIK era exclusivamente restrita às regiões da África e Ásia. No entanto, apesar da sintomatologia branda, a infecção pelo VZIK espalhou-se por outros continentes e ocasionou largas epidemias, levando a hipótese de possível capacidade pandêmica, devido sua rápida disseminação associada a evolução genética viral e aos fatores imunológicos de hospedeiros (AMORIM MT, et al., 2020).

Inicialmente, esperava-se uma neutralização endêmica esporádica do agente, concomitante a sua delimitação local, uma vez que, somente surtos esporádicos eram relatados, sustentando-se na hipótese de adaptação do vetor artrópode pelo clima local. Nessa perspectiva, a ação ineficaz de políticas públicas, permitiu o estabelecimento de largas epidemias, tornando dessa forma, susceptível a expansão da doença, devido a sua disseminação contínua, associada a adaptação do agente às distintas condições geográficas (MUSSO D e GLUBER DJ, 2016).

O VZIK classifica-se como um arbovírus, contendo genoma formado por RNA fita simples com polaridade positiva, responsável por codificar três proteínas estruturais ( $C$, prM / M e E) e sete proteínas não-estruturais (NS1, NS2A, NS2B, NS3, NS4A, NS4B e NS5). Esse arbovírus está contido na família Flaviviridae, gênero Flavivirus, têm a capacidade de ocasionar infecções assintomáticas em cerca de $80 \%$ dos casos, dentre as manifestações clínicas mais aparentes, destacam-se; febre, letargia, dor ocular, erupção cutânea, mialgia e artralgia (DANG J, et al., 2016; SHAN, et al., 2016).

Além disso, estudos reiteram a capacidade do VZIK apresentar disseminação multifacetada, distribuída na correlação trópica do vírus por diversos tipos de tecidos, destacando-se dessa forma, células de linhagem embrionária, caracterizada pela capacidade do VZIK possuir um papel determinante na microcefalia, que pode ter sua explicação fundamentada devido a desregulação do ciclo celular, ocasionando dessa forma a apoptose (ORGANIZAÇÃO MUNDIAL DA SAÚDE, 2018; LINDENBACH BD e RICE CM, 1997). 
Estudos envolvendo a relação vírus-hospedeiro demonstram que os genes envolvidos na resposta imune têm níveis de expressões alterados, devido a desregulação de RNAs não-codificantes, que são os mediadores responsáveis por atuar na manutenção e regulação gênica, assim como na sinalização e diferenciação celular; eventos cruciais durante o desenvolvimento embrionário (CASSEB SMM, et al., 2017).

Além disso, os mecanismos de defesa pelos quais as células utilizam-se como resposta à infecção viral, associados ainda, a expressão de genes reguladores, responsáveis pela codificação de proteínas, podem permitir o desencadeamento de processos celulares correlacionados à ativação de moduladores específicos estudados como alvos virais para a modulação do ciclo celular, apoptose e resposta imune, uma vez que o VZIK pode favorecer a baixa regulação gênica, de modo a reter uma resposta imune contra o agente infectante (SILVA LG, 2009).

De acordo com a base primordial estabelecida na biologia molecular, o dogma central propõe que o genoma humano possui organização de modo a conter na estrutura do DNA, todo o patrimônio genético de um organismo, independente da origem (BROSNANT CA e VOINNET O, 2008). Essa molécula, seria capaz de codificar por meio da transcrição, outra molécula de fundamental importância para o funcionamento da maquinaria celular e dos processos fisiológicos do organismo, a partir do RNA mensageiro (mRNA).

Apesar do impacto evidente dessa molécula na formação da identidade genética do organismo, sabe-se que aproximadamente $98 \%$ do genoma transcricional humano é representado por RNAs não-codificantes de proteínas (ncRNAs), sendo determinados por transcritos que não possuem quadros abertos de leitura (Open Reading Frames - ORF), sequências de base codificadoras de proteínas, dificilmente previstas em sequências genômicas, abrindo precedentes para a hipótese de que o total de genes codificadores de proteínas possa ser insuficiente para o complexo programa transcricional em vertebrados, ao passo em que ocorre o aumento da porcentagem do genoma transcrito com ncRNA em correlação à complexidade do organismo (MATTICK JS, 2003 e SILVA LG, 2009).

Os ncRNAs possuem funções diversas, sendo responsáveis pela repressão de alguns produtos moleculares e interferência durante a ativação das caspases apoptóticas, consequentemente desencadeando a apoptose. Além disso, podem interagir com outras moléculas como proteínas, DNA e RNAs, codificantes e não-codificantes que ocasionam mudanças fisiológicas, genéticas e epigenéticas na célula (CARNINCI $P$, 2008).

Com base nas perspectivas atribuídas, é possível aferir a importância das duas principais moléculas responsáveis durante a geração dos produtos de interação em infecção por VZIK; Os ncRNAs longos, sendo fundamentais na regulação (negativa ou positiva) durante a expressão gênica em eucariotos e procariotos, estabelecendo relação em processos como dosagem, compensação, impressão genômica, padrões de desenvolvimento, diferenciação e apoptose; Os ncRNAs curtos, assumindo funções determinantes em diversos organismos, apesar de sua limitação a eucariotos, regulando uma série de processos fundamentais de desenvolvimento da célula, bem como a supressão da replicação viral, à exemplo de interferências correlacionadas a expressão de produtos moleculares resultantes da infecção por VZIK (CARNINCI P, 2008 e COSTA FF, 2008).

Nessa perspectiva, em estudos realizados em humanos foi possível realizar a detecção de RNAs virais, em tecido materno e fetal, sendo estes originários da matriz placentária, do cordão umbilical, do líquido amniótico e durante o desenvolvimento fetal e neonatal do cérebro humano, revelando desta forma, um amplo tropismo tecidual por células progenitoras (ONORATI M, et al., 2016; GARCEZ PP, et al., 2016).

Corroborando portanto, para que os ncRNAs sejam expressos e regulados por mecanismos semelhantes que estão envolvidos no controle da codificação de genes em camundongos, estabelecendo a hipótese de que tais moléculas podem propiciar uma regulação específica que codifique proteínas essenciais para a replicação, determinando assim, a susceptibilidade permissiva do ciclo viral em células progenitoras para VZIK, compartilhando importantes características com genes codificadores de proteínas, uma vez que estes provaram possuir padrões específicos de expressão por tecidos (COSTA FF, 2005 e COSTA FF, 2007). O objetivo do estudo é apresentar por meio de uma revisão integrativa, a infecção pelo Vírus Zika (VZIK) em células progenitoras como causadora de desordem em expressão gênica a partir de seus mediadores, os RNAs não-codificantes (ncRNAs). 


\section{MÉTODOS}

Este trabalho, caracteriza-se como uma revisão integrativa observacional, de base transversal, fundamentada a partir de estudos que reiteram hipóteses acerca da desregulação na expressão de genes em infecção por VZIK em células progenitoras, distribuída nas fases de desenvolvimento teórico/prático, delimitadas a partir da identificação do tema, a partir da qual, delineou-se que perspectiva seria executada a proposta inicial de estudo: formulação da questão de pesquisa, caracterizada por estabelecer a execução do tema proposto, bem como a sua relevância para a comunidade científica; elaboração dos critérios de inclusão e exclusão de artigos, definição criteriosa dos filtros de pesquisa, de modo a restringir o campo de busca, promovendo a significação dos estudos mais relevantes; construção de instrumentos para coleta de dados relevantes dos artigos encontrados; consulta e busca e seleção dos Descritores de busca nas bases de dados e plataformas de acesso; avaliação e analise dos artigos selecionados na pesquisa; escolha do produto teórico para apresentação do estudo; interpretação e discussão dos resultados obtidos, a partir da qual discorreu-se acerca do produto técnico do trabalho, assim como a apresentação dos resultados obtidos e gerados após a seleção manual; apresentação da revisão juntamente com referencial teórico acerca do tema em questão, onde refinou-se os dados apresentados na pesquisa para a versão final.

O levantamento do material obtido na literatura para registro dos resultados foi realizado no período de maio a junho de 2020. As bases de dados utilizadas na triagem de material, foram as plataformas de busca: Nature, Medical Literature Analysis and Retrieval System Online (Medline), Science Direct e o Repositório Digital do Instituto Evandro Chagas (Patuá), o estudo conferiu prioridade a trabalhos publicados na língua inglesa e portuguesa.

As palavras-chave pesquisadas foram: ZIKV, ncRNA, miRNA, IncRNA, siRNA. Para apuramento dos artigos, determinou-se como critérios de inclusão: artigos publicados entre 2008-2020, privilegiando estudos recentes acerca da temática; textos disponibilizados na íntegra; pesquisas científicas classificadas como originais e indexadas nas bases de dados e artigos disponíveis nos idiomas português e inglês.

Para tanto, foram excluídos: Artigos publicados anteriormente ao ano de 2008; publicações repetidas em duas ou mais bases de dados; publicações disponíveis somente em forma de resumo; estudos em formato de carta; trabalhos voltados para a anatomia corporal e pesquisas científicas classificadas como originais, porém, que não tiveram como sujeitos de estudo a abordagem do tema proposto.

Portanto, foram extraídos os dados de utilidade nos artigos com base em informações configuradas nas seguintes variáveis: variáveis: (i) o autor, e ano de publicação do artigo; (ii) estudos experimentais; (iii) técnicas moleculares utilizadas; (iv) mecanismos de interação; (v) relevância dos resultados apresentados no estudo. Mediante aos títulos, foram designados os artigos para avaliação independente dos resumos. Os resumos dos artigos selecionados foram lidos na integra e forneceram resultados significantes, demonstrando em quadros, posteriormente.

\section{RESULTADOS}

Foram identificados após busca sistematizada, o total de 72 estudos relacionados a expressão de ncRNAs em infecções por vírus Zika, sendo estes registrados em correspondência quantitativa após delimitação dos critérios de exclusão, configuradas segundo as variáveis estabelecidas, com Science Direct $(n=27)$, Patuá (22), Medline $(n=17)$ e Nature $(n=6)$, a partir da busca fundamentada na restrição significativa dos resultados, pela intercalação cruzada dos descritores e adição dos operadores boleanos, de modo a restringir os parâmetros de busca e tornar susceptível o processo de seleção dos estudos encontrados acerca do tema.

Para tanto, após triagem dos registros obtidos pela busca nos bancos de dados, obteve-se como produto final dos artigos incluídos na revisão, 8 trabalhos que retratavam a proposta do tema, sendo o restante descartado a partir dos seguintes critérios; Inadequação do período de busca $(n=24)$; Divergência de Tema $(n=15)$; Intercorrência de acesso a pesquisa $(n=13)$; Relevância dos resultados obtidos $(n=12)$ (Quadro 1). 


\section{Revista Eletrônica Acervo Saúde / Electronic Journal Collection Health | ISSN 2178-2091}

Quadro 1 - Registro e síntese dos estudos selecionados na pesquisa.

\begin{tabular}{|c|c|c|c|c|}
\hline Autor/ Ano & Título & Objetivo & Conclusão & Contribuição \\
\hline $\begin{array}{l}\text { Ferreira JFL, } \\
\quad 2020\end{array}$ & $\begin{array}{c}\text { Avaliação da } \\
\text { expressão do miRNA- } \\
15 \text { e vias de apoptose } \\
\text { durante a infecção por } \\
\text { vírus Zika }\end{array}$ & $\begin{array}{l}\text { Avaliar a expressão do } \\
\text { miRNA-15, envolvido na } \\
\text { regulação de fatores de } \\
\text { processos celulares. }\end{array}$ & $\begin{array}{c}\text { Os resultados permitem relacionar a expressão } \\
\text { de miRNA } 15 \text { e vias de apoptose durante a } \\
\text { infeç̧ão pelo VZIK, com base na exploração } \\
\text { dos mecanismos de defesa do hospedeiro } \\
\text { contra a infeç̧ão. }\end{array}$ & $\begin{array}{c}\text { Estudo experimental de base quantitativa } \\
\text { que estabeleceu bases aprofundadas de } \\
\text { modo a correlacionar a prática da } \\
\text { expressão de ncRNAs em processos } \\
\text { celulares, bem como a apoptose, após } \\
\text { infecção pelo vírus Zika em célula } \\
\text { progenitora renal. }\end{array}$ \\
\hline $\begin{array}{l}\text { Ferreira JFL, } \\
\quad 2020\end{array}$ & \begin{tabular}{|} 
Análise do perfil de \\
expressão dos \\
IncRNAs em células de \\
Rim Embrionário \\
Humano (HEK-293) \\
infectadas \\
experimentalmente \\
pelo vírus Zika
\end{tabular} & $\begin{array}{l}\text { Avaliar a cinética de infecção } \\
\text { em células de rim } \\
\text { embrionário humano (HEK- } \\
\text { 293) através da obtenção de } \\
\text { carga viral por RT-qPCR e } \\
\text { relacionar com possíveis } \\
\text { RNAs longos não- } \\
\text { codificantes (IncRNAs). }\end{array}$ & $\begin{array}{c}\text { De acordo com o presente estudo, foi possível } \\
\text { concluir que as células HEK-293 são } \\
\text { susceptíveis e permissíveis à infecção por } \\
\text { VZIK e que a infeç̧ão afeta diretamente no } \\
\text { perfil de expressão de IncRNAs reguladores de } \\
\text { processos celulares e, consequentemente, } \\
\text { prejudicando ou auxiliando na resposta imune } \\
\text { do hospedeiro. }\end{array}$ & $\begin{array}{c}\text { Os achados da pesquisa, possibilitaram } \\
\text { aferir aspectos referentes a função do Inc- } \\
\text { RNA no hospedeiro, além de estabelecer a } \\
\text { necessidade da compreensão das } \\
\text { estratégias virais na evasão de resposta } \\
\text { imune, de modo a tornar susceptível o } \\
\text { entendimento da ação viral dentro da célula } \\
\text { infectada. }\end{array}$ \\
\hline $\begin{array}{l}\text { Chen L, et al, } \\
2018\end{array}$ & $\begin{array}{l}\text { LncRNA, MiRNA } \\
\text { IncRNA - MiRNA } \\
\text { interations in viral } \\
\text { infections }\end{array}$ & $\begin{array}{l}\text { Abordar a geração, a } \\
\text { classificação/mecanismos } \\
\text { regulatórios de IncRNA e } \\
\text { miRNA na relação entre } \\
\text { vírus-hospedeiro }\end{array}$ & $\begin{array}{l}\text { Os resultados indicam ideias relacionadas aos } \\
\text { efeitos dos mecanismos em transcrições } \\
\text { noncod em modelos humanos e a interação de } \\
\text { IncRNA e miRNA durante o ciclo viral e } \\
\text { resposta imune do hospedeiro. }\end{array}$ & $\begin{array}{l}\text { Elaboração teórica de hipóteses acerca das } \\
\text { variedades de mecanismos virais de } \\
\text { adaptação as células hospedeiras e a } \\
\text { importância dos avanços técnicos } \\
\text { experimentais na aplicação dos ncRNAs } \\
\text { utilizando-os como estratégias antivirais. }\end{array}$ \\
\hline $\begin{array}{c}\text { Gebert LFR e } \\
\text { MacRae IJ, } \\
2019\end{array}$ & $\begin{array}{l}\text { Regulation of miRNA } \\
\text { function in animals }\end{array}$ & $\begin{array}{l}\text { Avaliar os mecanismos } \\
\text { responsáveis durante a } \\
\text { modulação, atividade, } \\
\text { estabilidade e localização do } \\
\text { miRNA, por processamento } \\
\text { alternativo/maturação, } \\
\text { edições de sequência, } \\
\text { modificações pós - tradução } \\
\text { de proteínas argonautas, } \\
\text { fatores virais/ regulação das } \\
\text { interações do miRNA. }\end{array}$ & $\begin{array}{c}\text { Os resultados fornecem uma compreensão } \\
\text { inicial acerca da função dos microRNAs, } \\
\text { formando uma rede complexa que regula a } \\
\text { diferenciação, o desenvolvimento e } \\
\text { homeostase celular, atuando como regulador } \\
\text { de processos biológicos em células animais } \\
\text { embrionárias. }\end{array}$ & $\begin{array}{l}\text { Implantação teórica da base da natureza } \\
\text { dos microRNAs pela desregulação da sua } \\
\text { função, associada a expressão de tais } \\
\text { moléculas em células linhagem embrionária } \\
\text { derivadas do fígado de camundongos. }\end{array}$ \\
\hline
\end{tabular}




\section{Revista Eletrônica Acervo Saúde / Electronic Journal Collection Health | ISSN 2178-2091}

\begin{tabular}{|c|c|c|c|c|}
\hline Autor/ Ano & Título & Objetivo & Conclusão & Contribuição \\
\hline $\begin{array}{c}\text { Miner JJ e } \\
\text { Diamond MS, } \\
2018\end{array}$ & $\begin{array}{l}\text { Zika vírus } \\
\text { pathogenesis and } \\
\text { tissue tropism }\end{array}$ & $\begin{array}{l}\text { Descrever os avanços } \\
\text { recentes acerca da } \\
\text { compreensão da patogênese } \\
\text { do VZIK, tropismo dos tecidos } \\
\text { e manifestações clínicas } \\
\text { resultantes da infecção. }\end{array}$ & $\begin{array}{c}\text { Os resultados obtidos revelaram o tropismo } \\
\text { acentuado do VZIK por células progenitoras } \\
\text { em infecção placentária e congênita, } \\
\text { descrevendo a necessidade desses modelos } \\
\text { experimentais para o estudo da patogênese do } \\
\text { VZIK. }\end{array}$ & $\begin{array}{l}\text { Destacou os efeitos das manifestações nos } \\
\text { órgãos - alvo após infecção por VZIK, e } \\
\text { sugeriu a permanência de ideais ainda não } \\
\text { esclarecidos sobre a genética viral, a } \\
\text { patogênese do VZIK, bem como as } \\
\text { implicações neurais no desenvolvimento } \\
\text { embrionário durante infecção congênita. }\end{array}$ \\
\hline $\begin{array}{l}\text { Fecury PCMS, } \\
\text { et al., } 2020\end{array}$ & $\begin{array}{l}\text { Avaliação do perfil de } \\
\text { expressão de genes } \\
\text { relacionados a via de } \\
\text { miRNA's e apotose em } \\
\text { células neurais } \\
\text { infectadas pelo vírus } \\
\text { zika (VZIK) }\end{array}$ & \begin{tabular}{|} 
Determinar o perfil de \\
expressão de genes que \\
codificam proteínas-chave \\
relacionadas ao microRNA e \\
vias de apoptose em células \\
neurais de roedores da \\
família Muridae infectadas \\
por esse vírus.
\end{tabular} & $\begin{array}{l}\text { A infecção ZIKV em células N2A modificou a } \\
\text { expressão de proteínas importantes para o } \\
\text { processo imunológico, para a apoptose, e } \\
\text { proteínas envolvidas na biogênese de miRNA. }\end{array}$ & $\begin{array}{c}\text { O autor sugere que a formação de miRNAs } \\
\text { influencia a expressão de caspases e } \\
\text { citocinas, mostrando que a infecção viral } \\
\text { pode modificar a expressão de receptores } \\
\text { importantes para a detecção de RNA viral e } \\
\text { receptores importantes para a ativação em } \\
\text { via de apoptose }\end{array}$ \\
\hline $\begin{array}{c}\text { Brosnan CA, } \\
\text { Voinnet O, } \\
2008\end{array}$ & $\begin{array}{l}\text { The long and the short } \\
\text { of noncoding RNAs. }\end{array}$ & $\begin{array}{c}\text { Descrever como os ncRNAs } \\
\text { são codificados processados, } \\
\text { como operam, bem como as } \\
\text { suas funções celulares. }\end{array}$ & $\begin{array}{l}\text { O autor concentra-se em esclarecer exemplos } \\
\text { de classes de ncRNAs, a fim de implicá-los } \\
\text { como produtos da regulação de genes } \\
\text { codificadores de proteínas e seu papel no } \\
\text { espectro evolutivo das células. }\end{array}$ & $\begin{array}{l}\text { Descreve o papel de alguns ncRNAs, em } \\
\text { função isolada e estabelece ideais de } \\
\text { funcionamento prévio sistematizado, para } \\
\text { assim, caracterizar hipóteses relacionadas a } \\
\text { regulação de diversos ncRNAs em } \\
\text { ambientes específicos e em estágios de } \\
\text { desenvolvimento distintos, sugerindo papeis } \\
\text { biológicos, sob rígido controle. }\end{array}$ \\
\hline $\begin{array}{c}\text { Costa FF, } \\
2008\end{array}$ & $\begin{array}{l}\text { Non-coding RNAs, } \\
\text { epigenetics and } \\
\text { complexity. }\end{array}$ & $\begin{array}{l}\text { Discutir a relação dos } \\
\text { ncRNAs como os mais } \\
\text { importantes produtos de } \\
\text { organismos complexos } \\
\text { adquiridos durante a } \\
\text { evolução humana. }\end{array}$ & $\begin{array}{c}\text { É proposto um modelo a partir do qual } \\
\text { estabelece a epigenética como o principal fator } \\
\text { que determina o genótipo, capaz de moldar } \\
\text { características em organismos complexos, } \\
\text { sugerindo, portanto, que a maioria das porções } \\
\text { não codificantes transcritas de genomas } \\
\text { eucariotos são implicados direta e } \\
\text { indiretamente em produtos moleculares não } \\
\text { codificantes de proteínas. }\end{array}$ & $\begin{array}{l}\text { Promove a hipótese de que os ncRNAs } \\
\text { podem ter associação evolutiva com } \\
\text { fenótipos alternativos no mesmo genoma, } \\
\text { direcionando a metilação da citosina e } \\
\text { alteração de histonas, relacionados a } \\
\text { fenômenos genéticos que produzem } \\
\text { associações com células embrionárias, a } \\
\text { partir de interações direta ou indiretamente } \\
\text { correlacionados aos produtos do RNA viral. }\end{array}$ \\
\hline
\end{tabular}

Legenda: miRNA (microRNA), ncRNA (non-coding RNA), IncRNA (long non-coding RNA).

Fonte: Amorim MT, et al., 2020. 


\section{DISCUSSÃO}

A complexidade aprofundada na busca pela compreensão acerca dos mecanismos de interação molecular entre genoma, hospedeiro e vetores, são delineadores de perspectivas voltadas para a resolução de debates sobre os mecanismos de propagação de infecções virais, fundamentada no estabelecimento da persistência viral, junto a uma cadeia de mecanismos imunogenéticos que corroboram à replicação do VZIK que, nessa perspectiva, associada a expressão de produtos moleculares codificadores de proteínas, demonstram a necessidade por estudos que promovam o debate baseado na busca dos mecanismos de interação do hospedeiro, associados a origem de moléculas mediadoras não codificadoras na imunopatogênese viral (BROGUEIRA P e MIRANDA AC, 2017). Nessa perspectiva, Miner JJ e Diamond MS (2018), descrevem em seu estudo, mecanismos potenciais relacionados a expressão de apoptose em células progenitoras neurais humanas, ressaltando o impacto no neurodesenvolvimento do cérebro, de modo a correlacionar a parâmetros clínicos significativos na infecção por VZIK.

Portanto, é possível determinar o impacto resultante da inoculação intravencular direta de VZIK em cérebros de fetos de camundongos selvagens, ocasionando a inibição da diferenciação de células progenitoras e microcefalia, diante a possibilitar a confirmação da morte celular e degradação das células do córtex cerebral em um modelo animal. Miner JJ e Diamond MS (2018), ainda ressalta a deteç̧ão de RNA viral em tecidos maternos e fetais, sendo eles originários da matriz placentária, do cordão umbilical, do líquido amniótico e durante o desenvolvimento fetal. Por conseguinte, nota-se que não somente modelos animais possuam expressão de produtos gênicos facilitadores da replicação viral, associados ao VZIK, justificado pelo tropismo multifacetado do vírus por células progenitoras em mamíferos.

Em uma outra perspectiva, Costa FF (2008) destaca os impactos gerados pela expressão de produtos moleculares no material genético, de modo a modificar a conformação na molécula de DNA celular, sem ocasionar alterações significativas nas cadeias de aminoácidos, sugerindo a participação dos ncRNAs no perfil de expressão de genes a partir da segmentação, gastrulação e organogênese embrionária; com associação direta ao tropismo tecidual.

Sob a mesma hipótese, Brosnan CA e Voinnet O (2008), reiteram a expressão de ncRNAs em cérebros de camundongos - por hibridização in situ - permitindo a associação - em infecção por VZIK - por tecidos específicos, tipos de células e compartimentos subcelulares, a partir de lócus intergênicos antissentidos às proteínas e genes codificadores de importância neurológica, sugerindo a transposição de subprodutos celulares que interagem com esses genes, alterando positivamente ou negativamente a replicação viral e ativação de processos celulares. Ainda é possível observar na abordagem realizada pelos autores, a tentativa de induzir a escassez de estudos realizados acerca das funções dos RNAs não codificadores de proteínas e a necessidade da busca pela função dessas moléculas em células eucarióticas, em virtude do volume de ncRNAs agregado ao genoma de camundongos.

Gebert LFR e MacRae IJ (2019) revisam em seu estudo, os mecanismos responsáveis por modular a atividade do miRNA (micro RNA), que como RNAs não codificantes de cadeia curta, são responsáveis por participar no silenciamento de genes, reiterando assim, a relação dessas moléculas durante os processos celulares do desenvolvimento animal, diferenciação celular e homeostase; bem como as deleções dos fatores de biogênese de miRNA fundamentais Dicer e Drosha - complexo héterotrimérico determinados multiprocssador, fundamental na biogênese de microRNA - significantes na ativação da apoptose em tecidos embrionários de camundongos.

Ainda que, os autores busquem ressaltar o papel das estruturas secundárias dos mRNA no reconhecimento do miRNA-alvo, haja vista que as estruturas responsáveis por tornar inacessível os sítios ativos dos miRISC (RNA-induced silencing complex) podem inibir o silenciamento, diretamente associado a expressão de genes codificadores de proteínas em infecções virais, de modo a promover e ativação positiva ou negativa em processos apoptóticos, levantando assim, a hipótese de que essas estruturas podem permitir o reconhecimento por miRNAs, apesar das interações entre RNA e Argonauta, bem como o grau de modulação da resposta antiviral a partir do direcionamento dos miRNAs permanecerem desconhecidas. 
Fecury PCMS, et al. (2020), torna possível, o estabelecimento de evidências que associem a expressão dos miRNAs na replicação e propagação viral em infecção por VZIK, de modo que, em espectro geral, a expressão e direcionamento das diversas classes dos ncRNAs, possam estar envolvidas em respostas antivirais celulares, uma vez que os miRNAs sejam capazes de ter sua codificação por um genoma viral, podem também, compartilhar sequências semelhantes aos miRNAs virais, ou ter sequências completamente distintas, abrindo precedentes para a hipótese de que a variedades dos grupos de ncRNAs conferem também a capacidade de regular uma gama multivariada de processos biológicos relacionados a infecção viral, haja vista que, o autor conclui seu estudo atribuindo destaque a formação dos miRNAs como influenciadores diretos durante a ativação de caspases e produção de citocinas.

Ainda, foi possível evidenciar em Ferreira JFL (2020), que a infecção por VZIK tem a capacidade de modificar a expressão de receptores importantes para a detecção de RNA viral (RIG-I) no ambiente intracelular, assim como a expressão de receptores importantes para a ativação em via de apoptose (FAS-L). Tendo como base experimental, objetos de estudo semelhantes, Ferreira JFL (2020), possibilitou relacionar a expressão de miRNA-15 e vias de apoptose durante a infecção pelo VZIK, tomando assim, como perspectiva metodológica, a exploração dos mecanismos de defesa do hospedeiro contra a infecção.

Diante desses aspectos, os resultados encontrados permitiram observar que a carga viral do VZIK está correlacionada com a ativação das vias de caspases apoptóticas e, apesar dos mecanismos de infecção do VZIK estarem bem estabelecidos, é notável a alteração por meio de diversas vias metabólicas celulares, ainda que, de modo a visar o favorecimento do hospedeiro pelo desenvolvimento de uma resposta imune, ou de modo a manter o ciclo de replicação viral, propondo a necessidade por estudos que viabilizem a busca pela biogênese dos grupos de ncRNAs em seu aspecto mais individualizado, para que, por conseguinte sejam desenvolvidos estudos sistematizados a fim de relacionar a infecção do VZIK com os mecanismos de resposta da célula.

Em Ferreira JFL, et al. (2020), o estudo possibilitou observar a ativação de genes relacionados a resposta imune, mostrando que os IncRNAs são de fundamental importância para a determinação da função e atividade gênica, corroborando dessa forma, para a importância de da compreensão das suas ações durantes infecções virais. Nessa perspectiva, o mesmo estudo também demonstrou que em infecção por VZIK em células HEK-293, ocorreu a progressão de disfunções celulares, devido às regiões afetadas no genoma do hospedeiro, resultando na desregulação de genes, resultando assim, em diversas alterações em produtos de regulação gênica e, por conseguinte, nos mecanismos imunológicos do hospedeiro diante da infecção.

Ainda, sob mesma abordagem, Chen L, et al. (2018) destaca em seu estudo, os IncRNAs e os miRNAs, como produtos epigenéticos e subcelulares vitais durante as reações biológicas em função celular policamada, ressaltando assim, a relação dos recursos e mecanismos comuns das transcrições não codificadas, bem como os paradigmas regulatórios durante a infecção viral, a partir de redes complexas e independentes responsáveis por programar a expressão imediata de genes codificadores de proteínas, associados a infecção por VZIK. Diante desses aspectos, se estabelece, em função geral, os vírus como substâncias exógenas, capazes de explorar uma variedade de estratégias ativas de adaptação do microambiente às células hospedeiras, implicando a interação dos IncRNAs e miRNAs em células progenitoras, como potenciais alvos na aplicação terapêutica durante infecções virais.

\section{CONSIDERAÇÕES FINAIS}

Após avaliação generalizada dos estudos registrados, verificou-se verossimilhança fundamentada na abordagem do objeto de pesquisa, seguindo uma linha de pensamento baseada na busca pela função dos ncRNAs, relação epigenética durante infecção por VZIK e ativação de mediadores imunológicos, bem como a expressão de produtos gênicos associados a processos celulares correspondentes aos recursos de defesa do hospedeiro e aos mecanismos de replicação viral. Diante dos produtos obtidos, esse estudo possibilitou relacionar fundamentos teóricos, preponderantes acerca do tropismo viral por tecidos específicos, como observou-se na maior parte dos trabalhos abordados, que descreviam a expressão de ncRNAs em células 
progenitoras durante a infecção pelo VZIK. Assim, foi possível observar a importância de estudos que proporcionem a contribuição técnica experimental, sobre os mecanismos de replicação viral, tropismo celular, atividade imunogenética, bem como a ação de mediadores celulares e ativadores de respostas imunológicas, de modo a fomentar a contribuição científica para o controle do VZIK.

\section{REFERÊNCIAS}

1. AMORIM MT, et al. Determinação molecular comparativa de formas de DNA viral em arbovirus de RNA da família flaviviridae, Brazilian Journal of Health Review, 2020, 3(3): 5651-5656.

2. BROGUEIRA P, MIRANDA AC. Vírus Zika: Emergência de um velho conhecido. Medicina Interna, 2017,24 (2): 146153.

3. BROSNAN CA, VOINNET O. The long and the short of noncoding RNAs. Current Opinion in Cell Biology, Strasbourg, 2008, 21, 416:425.

4. CARNINCI P. Non-coding RNA transcription: turning on neighbours. Nature Cell Biology, Londres, 2008, 10, 1023:1024.

5. CASSEB SMM, et al. Os mRNA's drosha, dgcr8 e dicer são sub -regulados em células humanas infectadas pelo vírus da dengue 4 e desempenham um papel na patogênese viral. Genet Mol Res 2017, 2981-2999.

6. COSTA FF. Non-coding RNAs, epigenetics and complexity. Gene, Chicago, 2008, 410, 9:17.

7. COSTA FF. Non-coding RNAs: Lost in translation. Gene, Chicago, 2007, 386, 1:10.

8. COSTA FF. Non-coding RNAs: New players in eukaryotic biology. Gene, Chicago, 2005, 357, 83:94

9. CULLEN BR. Viruses and microRNAs. Nature Genetics, 2006, 38: 26-30.

10. DANG J, et al. Zika Virus Depletes Neural Progenitors in Human Cerebral Organoids through Activation of the Innate Immune Receptor TLR3. Cell Stem Cell. 2016, 19: 258-265.

11. FECURY PCMS, et al. Avaliação do perfil de expressão de genes relacionados a via de microRNA's e apotose em células neurais infectadas experimentalmente pelo vírus zika (ZIKV), Brazilian Journal of Health Review, 2020, 3 (3).

12. FERREIRA JFL. Avaliação da expressão do miRNA-15 e vias de apoptose durante a infecção por vírus Zika. Trabalho de Conclusão de Curso, Escola Superior da Amazônia, 2018.

13. FERREIRA JFL. Análise do perfil de expressão dos IncRNAs em células de Rim Embrionário Humano (HEK-293) infectadas experimentalmente pelo vírus Zika. Programa de Pós Graduação de Virologia do Instituto Evandro Chagas, Belém-PA, Dissertação de Mestrado, 2020.

14. GARCEZ PP, et al. Zika virus impairs growth in human neurospheres and brain organoids. Science, 2016, 352-816.

15. GEBERT LFR e MACRAE, Regulation of miRNA function in animals. Nat. Rev. Mol. Biol. Cell, 20(1): 21-37, 2019.

16. LINDENBACH BD, RICE CM. Trans-complementação do vírus da febre amarela ns1 revela um papel na replicação precoce do RNA. J Virol, 1997, 71: 9608-9617.

17. MATTICK, JS. Challenging the dogma: the hidden layer of non-protein-coding RNAs in complex organisms. BioEssays, Cambridge, 2003, 25, 930:939.

18. MUSSO D, GUBLER DJ. Zika Virus. Clin Microbiol Rev. 2016; 29: 487-524.

19. ONORATI M, LI Z, et al. Zika Virus Disrupts Phospho-TBK1 Localization and Mitosis in Human Neuroepithelial Stem Cells and Radial Glia. Cell Reports. 2016, 16: 2576 - 2592.

20. SHAN C, et al. Um clone de cDNA infeccioso do vírus zika para estudar a virulência viral, a transmissão de mosquitos e os inibidores antivirais. Cell Host Microbe. 2016, 19: 891-900

21. SILVA LG, Os papeis dos RNAs não codificantes no desenvolvimento embrionário: Um panorama geral. Trabalho de Conclusão de Curso de Ciências Biológicas, Universidade Estadual Paulista, Rio Claro, 2009. 